\title{
Assessment of Genetic Variability, Heritability and Genetic Advance in Indian Mustard [Brassica juncea L. Czern \& Coss.]
}

\author{
Sarvesh Kr. Maurya*, K.N. Maurya, Kanhaiya Lal, Yogendra Singh, Sujit Singh, \\ Brijesh Dixit and Soni Singh
}

\author{
Department of Genetics and Plant Breeding, Narendra Deva University of Agriculture and \\ Technology, Kumarganj, Faizabad-224229 (U.P.) India
}

*Corresponding author

\begin{tabular}{|l|}
\hline Ke y w o r d s \\
Indian mustard (Brassica \\
juncea L. Czern \& Coss.), \\
$\begin{array}{l}\text { Selection parameters, } \\
\text { Genetic variability, } \\
\text { Heritability and genetic } \\
\text { advance }\end{array}$ \\
\hline Article Info \\
\hline $\begin{array}{l}\text { Accepted: } \\
\text { 04 October } 2018 \\
\text { Available Online: } \\
\text { 10 November } 2018\end{array}$ \\
\hline
\end{tabular}

\section{Introduction}

Brassica juncea is the second most important oilseed crop in the country after groundnut which accounts for nearly $30.7 \%$ of the total oilseed production in the country. India's share in global production of mustard oil was around 9.0 percent in 2015-16. India was the 7th largest oil importing country in 2014-15 (Anonymous 2016). Indian mustard [Brassica juncea L. Czern \& Coss.], which is cultivated throughout the world belongs to the family Cruciferae (Brassicaceae) under the genus Brassica, cultivated all over India and it is the 
major rabi oilseed crop of northern India. It has 38 to $42 \%$ oil and $24 \%$ protein. Since, Brassica juncea is the second most important oilseed crop in the country, it should be emphasized to increase quality and quantity of oil in Brassica juncea to provide best diet to our Indians. For the fulfilment of this objective it is essential that the breeding material must contain sufficient amount of genetic variability since, the success of any breeding programme depends upon the genetic variability engraved in the breeding material.

The assessment of parameters including phenotypic and genotypic coefficients of variation, heritability in broad sense, and genetic advance as \% of mean is a prerequisite for making effective selection. Information on the nature and magnitude of variability and heritability in a population is one of the prerequisite for successful breeding programme in selecting genotypes with desirable characters. It is therefore, of great importance for breeder to know the heritability of the agronomical characters to improve the yield of the crop effectively. Keeping these point under consideration the present investigation is carried out.

\section{Materials and Methods}

An experiment on Indian mustard (Brassica juncea L. Czern \& Coss) was conducted in Randomized Block Design (RBD) accommodating 50 germplasm accessions along with three check varieties viz., Kranti, Narendra Rai and Vardan during Rabi 201617 at the research farm of Narendra Deva University of Agriculture and Technology, Kumarganj, Faizabad. These genotypes were obtained from various Rapeseed and Mustard centres located across the country. The length of the rows was kept 3 meter with a spacing of $45 \mathrm{~cm}$ between the rows and $15 \mathrm{~cm}$ between the plants. All the cultural practices were followed to raise a good crop.
Five competitive plants were randomly selected from each entry in each replication and were tagged for recording detailed field and laboratory observations. Data on various quantitative characters such as plant height $(\mathrm{cm})$, number of primary branches per plant, number of secondary branches per plant, length of main raceme $(\mathrm{cm})$, number of siliqua on main raceme, number of seeds per siliqua,1000-seed weight(g), biological yield per plant(g), harvest index(\%), oil content (\%), seed yield per plant $(\mathrm{g})$ were recorded on the basis of five randomly selected plants, while data on two characters such as days to 50percent flowering, days to maturity were recorded on plot basis.

Analysis of variance (ANOVA) for Randomized Block Design for all attributes (major and minor) was done using statistical software. Analysis of variance and the genetic parameters were computed by following standard statistical procedure (Table 1). The mean data were subjected to analysis of variance as per standard procedure outlined by Panse and Sukhatme (1967). The Phenotypic Coefficient of Variation (PCV), Genotypic Coefficient of Variation (GCV) and heritability in broad sense were calculated using the formula suggested by Burton and de Vane (1953). Genetic advance was calculated by the method suggested by Johnson et al., (1955).

\section{Results and Discussion}

The analysis of variance exhibited highly significant difference among the genotypes for all the characters indicating the presence of adequate amount of genetic variability among the genotypes. The mean performance of 50 entries of mustard genotypes for 13 characters is presented in (Table 2). The existence of genetic variability in the population provides sample opportunities for selection being effective. 
Table.1 Analysis of variance for 13 characters in mustard (Brassica juncea L. Czern \& Coss)

\begin{tabular}{|c|c|c|c|c|c|c|c|c|c|c|c|c|c|c|}
\hline $\begin{array}{l}\text { Source of } \\
\text { variation }\end{array}$ & $\begin{array}{l}\text { d. } \\
\text { f. }\end{array}$ & $\begin{array}{l}\text { Days to } \\
50 \% \\
\text { flowering }\end{array}$ & $\begin{array}{l}\text { Days to } \\
\text { maturity }\end{array}$ & $\begin{array}{l}\text { Plant } \\
\text { height } \\
(\mathrm{cm})\end{array}$ & $\begin{array}{l}\text { Primary } \\
\text { branches/ } \\
\text { Plant }\end{array}$ & $\begin{array}{l}\text { Secondary } \\
\text { branches/ } \\
\text { plant }\end{array}$ & $\begin{array}{l}\text { Main } \\
\text { raceme } \\
\text { length } \\
\text { (cm) }\end{array}$ & $\begin{array}{l}\text { Siliqua on } \\
\text { main } \\
\text { raceme }\end{array}$ & $\begin{array}{l}\text { Seeds/ } \\
\text { siliqua }\end{array}$ & $\begin{array}{l}1000- \\
\text { seed } \\
\text { weight } \\
\text { (g) }\end{array}$ & $\begin{array}{l}\text { Biological } \\
\text { yield } \\
(\mathrm{g})\end{array}$ & $\begin{array}{l}\text { Harvest } \\
\text { index } \\
(\%)\end{array}$ & $\begin{array}{l}\text { Oil } \\
\text { content } \\
\%\end{array}$ & $\begin{array}{l}\text { Seed } \\
\text { yield/ } \\
\text { plant } \\
\text { (g) }\end{array}$ \\
\hline Replications & 2 & 0.9866 & 5.0866 & 3.12 & 0.4066 & 5.0866 & 1.1266 & 5.9266 & 0.14 & 0.3244 & 14.6866 & 0.1667 & 0.161 & 5.82 \\
\hline Treatments & 49 & $16.1904 * *$ & $30.2352 * *$ & $492.944 * *$ & $1.5668^{*}$ & $24.296 * *$ & $128.28 * *$ & $70.1808 * *$ & $5.8787 * *$ & $3.0788 * *$ & $631.12 * *$ & $38.23 * *$ & $3.1634 * *$ & $28.75^{* *}$ \\
\hline Error & 98 & 2.3472 & 3.005 & 7.2288 & 1.0121 & 1.8213 & 3.4531 & 3.9334 & 0.9155 & 0.1262 & 4.9859 & 6.0733 & 0.071 & 2.47 \\
\hline
\end{tabular}

Table.2 Estimates of mean, range, coefficients of variation (\%), heritability and genetic advance for 13 characters in Indian mustard (Brassica juncea L. Czern \& Coss)

\begin{tabular}{|c|c|c|c|c|c|c|c|c|}
\hline \multirow{2}{*}{$\begin{array}{l}\text { S. } \\
\text { No. }\end{array}$} & \multirow[t]{2}{*}{ Characters } & \multirow[t]{2}{*}{ Mean } & \multirow[t]{2}{*}{ Range } & \multicolumn{2}{|c|}{ Coefficient of variation (\%) } & \multirow{2}{*}{$\begin{array}{l}\text { Heritability in } \\
\text { broad sense }(\%)\end{array}$} & \multirow{2}{*}{$\begin{array}{l}\text { Genetic } \\
\text { advance }\end{array}$} & \multirow{2}{*}{$\begin{array}{l}\text { Genetic advance } \\
\text { in }(\%) \text { of mean }\end{array}$} \\
\hline & & & & PCV & GCV & & & \\
\hline 1. & Days to $50 \%$ flowering & 41.86 & $37.00-49.00$ & 6.30 & 5.13 & 66.30 & 3.603 & 8.605 \\
\hline 2. & Days to maturity & 135.07 & $119.00-139.00$ & 2.57 & 2.23 & 75.10 & 5.379 & 3.983 \\
\hline 3. & Plantheight (cm) & 188.02 & $156.33-227.66$ & 6.91 & 6.76 & 95.70 & 25.646 & 13.640 \\
\hline 4. & Primarybranches/plant & 5.81 & $4.33-7.33$ & 18.82 & 7.39 & 15.40 & 0.348 & 5.989 \\
\hline 5. & Secondarybranches/plant & 12.21 & $6.00-19.33$ & 24.98 & 22.41 & 80.40 & 5.057 & 41.406 \\
\hline 6. & Mainraceme length (cm) & 64.23 & $46.66-73.66$ & 10.45 & 10.04 & 92.30 & 12.769 & 19.880 \\
\hline 7. & Siliquaonmainraceme & 44.40 & $34.66-62.66$ & 11.48 & 10.58 & 84.90 & 8.919 & 20.084 \\
\hline 8. & Seeds/siliqua & 13.86 & $11.33-17.00$ & 11.56 & 9.28 & 64.40 & 2.126 & 15.339 \\
\hline 9. & 1000-seed weight $(\mathrm{g})$ & 4.07 & $2.16-6.26$ & 25.84 & 24.33 & 88.60 & 1.924 & 47.188 \\
\hline 10. & Biological yield (g) & 64.29 & $28.33-98.66$ & 22.73 & 22.47 & 97.70 & 29.411 & 45.746 \\
\hline 11. & Harvest index (\%) & 23.65 & $16.83-34.79$ & 17.32 & 13.83 & 63.80 & 5.389 & 22.778 \\
\hline 12. & Oil content $\%$ & 39.27 & $37.46-41.39$ & 2.67 & 2.58 & 93.60 & 2.023 & 5.151 \\
\hline 13. & Seedyield/plant (g) & 14.98 & $8.00-22.33$ & 22.37 & 19.75 & 78.00 & 5.384 & 35.943 \\
\hline
\end{tabular}


For any sound breeding programme, it is essential to have a large variation in the material at the hand of breeder. The characters of economic important are generally quantitative in nature and exhibited a considerable degree of interaction with the environment.

The phenotypic coefficients of variation (PCV) were invariably slightly higher than their corresponding genotypic coefficients of variation (GCV) due to environmental influence (Table 2). The higher estimates of phenotypic (PCV) and genotypic (GCV) coefficient of variation were observed in the case of 1000-seed weight, secondary branches per plant, biological yield and seed yield per plant can be considered as high because of being very close to $20 \%$. Moderate estimates of PCV as well as GCV were recorded for, Primary branches/plant, harvest index, seeds per siliqua, siliqua on main raceme, main raceme in length. Generally the phenotypic coefficient of variation was higher than genotypic coefficient of variation which indicated that environment played a considerable role in expression of these traits. Relatively smaller values of environmental coefficients of variation (ECV) for these traits suggested that their phenotypic expression is less influenced by environments. Highest genetic variability was observed in Indian mustard for 1000-seed weight, secondary branches per plant as reported by Khan et al., (2006), Roy et al., (2011), Lohia et al., (2013) and Tele et al., (2014).

Knowledge of heritability of a character is important as it indicates the possibility and extant to which improvement is possible through selection Robinson et al., (1949). The efficiency of selection depends upon the magnitude of heritability of traits, because it measures the transmissibility of characters from parents to off-spring. Through the estimates of heritability in biometrical studies are influenced by method of estimation, generation of study, sample size and environment even through it helps the breeders during selection. The present study revealed that estimates of high heritability for different traits under study viz., biological yield, plant height, oil content, main raceme length, 1000-seed weight, siliqua on main raceme, secondary branches per plant, seed yield per plant and days to maturity, exhibited high estimates of heritability $(>75 \%)$, while the lowest value by primary branches per plant.

The highest value of genetic advance in per cent of mean was shown by 1000 -seed weight $(47.18 \%)$ while days of maturity $(3.98 \%)$ had lowest value for this parameter. The character exhibiting high estimates $(>20 \%)$ of genetic advance in per cent of mean were biological yield $(45.74 \%)$, secondary branches per plant (41.40\%), seed yield per plant $(35.94 \%)$, harvest index $(22.77 \%)$ and siliqua on main raceme $(20.08 \%)$ indicating that direct selection for these traits would be effective for the improvement. Moderate estimates of genetic advance in per cent of mean (10-20\%) were recorded for main raceme length $(19.88 \%)$, seed per siliqua $(15.339 \%)$, plant height $(13.64 \%)$ and its low estimate $(<10 \%)$ was recorded for days of $50 \%$ flowering $(8.60 \%)$, primary branches per plant $(5.98 \%)$, oil content $(5.15 \%)$ and days to maturity (3.98\%). The character having high heritability with high genetic advance generally indicates that heritability is more due to the additive gene effect and advocated the use of high estimates of heritability along with high magnitude of genetic advance for genetic improvement in any trait through selection. Higher heritability does not always ensure an increased genetic advance. Heritability estimates together with genetic advance are generally regarded to be more useful in predicting the grain through selection (Johnson et al., 1955). High 
heritability coupled with high genetic advance in per cent of mean was observed for yield components such as 1000-seed weight, biological yield, secondary branches per plant, seed yield per plant, harvest index and siliqua on main raceme and similar results were also observed by Singh et al., (2004), Upadhyay and Kumar (2009), Amit Singh et al., (2013), Tele et al., (2014), and Akabari and Niranjana (2015).

From all over the analysis, it can be concluded that the experimental material possess sufficient amount of genetic variability for most of the economic traits and a combination of various traits contributing to seed yield. In this study it is found that 1000seed weight, secondary branches plant, biological yield per plant, Seed yield per plant, length of main raceme and siliqua on main raceme showed maximum potential for effectiveness of selection, since these traits show high GCV, heritability and genetic advance. This would help us in designing the selection methodology which can further be utilized in the breeding programme for improvement of seed yield.

\section{References}

Akabari, V. R. and Niranjana, M. (2015). Genetic variability and trait association studies in Indian mustard (Brassica juncea). I. J. of Agricultural Sciences. 11(1):35-39.

Amit Singh, Ram Avtar, Dhiraj Singh, Sangwan, O. and Balyan, P. (2013). Genetic variability, character association and path analysis for seed yield and component traits under two environments in Indian mustard. $J$. of Oilseed Brassica, 4(1): 43-48.

Anonymous (2015-16). Agriculture Outlook and Situation Analysis Reports. Under the project commission by the National
Food Security Mission. Ministry of Agriculture (NCAER), pp-68.

Burton, G.M. and de Vane, E.H. (1953). Estimating heritability in tall fescue (Festuca arundinacea) from replicated clonal material. Agron. J., 45: 471-481.

Johnson, H.W., Robinson, H.F. and Comstock, R.E (1955). Estimation of genetic and environmental variability in soybean. Agron. J., 47: 314-318.

Johnson, H.W.; Robinson HF, Comstock RE. Estimates of genetic and environmental variability in soybeans. Agron. J. 1955; 47:314-318.

Khan, M.N.; Maqhdomi, M.I. and Wani, S.A. (2006). Genetic variability and character association in yield and related attributes in non-segregating population of gobhi sarson (Brassica napus L.). International J. of Agril. Sci., 2 (1): 56-60.

Lohia, R. S., Singh, R. K. and Mahak Singh (2013). Studies on genetic variability, heritability and character association in Indian mustard [Brassica juncea (L.) Czern \& Coss]. Progressive Research. 8 (1):75-77.

Panse, V.G. and Sukhatme, P.V. (1978). Statistical methods for Agricultural workers, III ${ }^{\text {rd }}$ edition, ICAR, New Delhi., 228-231.

Robinson HF, Comstock RE, Harvey PH. Estimates of heritability and degree of dominance in corn. Agron. J. 1949; 41:353-359.

Roy, S.K. Haque, S. Kale, V.A. Asabe, D.S. and Dash, S. (2011). Variability and character association studies in rapeseed-mustard (Brassica sp.). J. of Crop and Weed; 7 (2): 108112.

Singh, M.; Singh, H.L. and Dixit, S. (2004). Studies on genetic variability, heritability, genetic advance and correlation in Indian mustard [Brassica juncea (L.) Czern and Coss.]. Plant Archives. 4(2): 291-294. 
Tele, R. B., Patil, S. R., Lole, M. D., Khillari, A. V., Solanke, P. D and Bansod, S. C. (2014) Genetic analysis in Indian mustard (Brassica juncea) through diallel mating. Journal of Oilseed Brassica;. 5 (1):55-60.

Upadhyay, D.K. and Kumar, K. (2009). Analysis of heritability and genetic advance in relation to yield and its components in Indian mustard [Brassica juncea (L.) Czern and Coss.] Under normal and late sown conditions. International Journal of Plant Sciences (Muzaffarnagar), 4(1): 12-14.

\section{How to cite this article:}

Sarvesh Kr. Maurya, K.N. Maurya, Kanhaiya Lal, Yogendra Singh, Sujit Singh, Brijesh Dixit and Soni Singh. 2018. Assessment of Genetic Variability, Heritability and Genetic Advance in Indian Mustard [Brassica juncea L. Czern \& Coss.]. Int.J.Curr.Microbiol.App.Sci. 7(11): 1318. doi: https://doi.org/10.20546/ijcmas.2018.711.002 